\title{
Antibacterial activity of a laboratory made cosmetic cream Vs marketed creams containing bee honey
}

\section{RADM Ranasinghe $^{1}$, TMIUK Tennakoon ${ }^{1}$}

Introduction and Objectives: Many cosmetic products in the market contain bee honey and the aim of this study was to compare the antibacterial activity of a laboratory made cosmetic cream containing Sri Lankan raw honey with marketed creams containing honey from local and international sources.

Methods: The natural honey of Apiscerana collected from Sabaragamuwa province in Sri Lanka was used in making a series of oil in water emulsions based vanishing creams by incorporating different weights of honey mixture $\left(\mathrm{F}_{1}-12.5 \% \mathrm{w} / \mathrm{w}, \mathrm{F}_{2}-18.75 \% \mathrm{w} / \mathrm{w}\right.$ and $\mathrm{F}_{3^{-}}$ $25 \% \mathrm{w} / \mathrm{w}$ ) according to a previously developed formulation. These formulations were compared with three commercially available creams containing honey - $\mathrm{C}_{1}$ (local honey), $\mathrm{C}_{2}$ (foreign honey) and $\mathrm{C}_{3}$ (foreignhoney) - to determine the stability via accelerated stability testing and antibacterial activity via agar well diffusion assay against Escherichia coli using gentamicin as the control. Wells were prepared in agar plates using an $8 \mathrm{~mm}$ diameter corkborer. All experiments were carried out in triplicate.

Results: All cream formulations were stable at room temperature $\left(25^{\circ} \mathrm{C}\right)$ and all cream formulations produced inhibitory zones against $E$. coli(Table 1). $F_{2}$ and $F_{3}$ showed significantly higher zones of inhibition $\left(\mathrm{F}_{2}-\mathrm{C}_{2} \mathrm{p}=0.009 ; \mathrm{F}_{2}-\mathrm{C}_{3} \mathrm{p}=0.038 ; \mathrm{F}_{3}-\mathrm{C}_{2} \mathrm{p}=0.005 ; \mathrm{F}_{3}-\mathrm{C}_{3}\right.$ $\mathrm{p}=0.019$ ) compared to $\mathrm{C}_{2}$ and $\mathrm{C}_{3}$, while the zone of inhibition of $\mathrm{F}_{1}$ was significantly higher $(p=0.024)$ compared to $C_{2}$. However, there was no significant difference between the zones of inhibition observed between $\mathrm{C}_{1}$ and all laboratory made creams.

Table1: Inhibitory zones against E. coli.

\begin{tabular}{|c|c|}
\hline Cream type & $\begin{array}{c}\text { Diameter of zone } \\
\text { of inhibition (mm) }\end{array}$ \\
\hline$F_{1}$ & $19.5 \pm 2.12$ \\
\hline$F_{2}$ & $21.0 \pm 1.41$ \\
\hline$F_{3}$ & $24.0 \pm 1.41$ \\
\hline$C_{1}$ & $26.5 \pm 3.54$ \\
\hline$C_{2}$ & $09.5 \pm 0.71$ \\
\hline$C_{3}$ & $14.0 \pm 1.41$ \\
\hline
\end{tabular}

Conclusions:The inhibition zones against $E$. coli increased with increasing honey concentration of laboratory made creams. These showed similar inhibition zones against $E$. colito the commercial product containing local honey compared with the commercial products containing foreignhoney.

Keywords: Antibacterial activity, Sri Lankan raw honey, cosmetic creams, E. coli

\footnotetext{
${ }^{1}$ Department of Pharmacy, Faculty of Allied Health Sciences, University of Peradeniya, Sri Lanka

Address for correspondence: RADM Ranasinghe. Telephone: +94710743650

Email:ahs15pcy011@ahs.pdn.ac.lk (D) https://orcid.org/0000-0002-5395-0574
} 